\title{
Evidence of hyperpycnal flows at the head of the meandering Kaoping Canyon off SW Taiwan
}

\author{
Cheng-Shing Chiang $\cdot$ Ho-Shing Yu
}

Received: 25 May 2006 / Accepted: 17 December 2007 / Published online: 5 January 2008

(C) Springer-Verlag 2007

\begin{abstract}
Using seismic and Chirp sonar profiles, this paper tests the hypothesis that hyperpycnal flows are the main factor controlling the formation and maintenance of the meandering Kaoping submarine canyon off SW Taiwan. Cross-section geometries, and erosional as well as depositional features vary along the canyon course. In the proximal, sinuous part of the canyon, down-cutting into the shelf strata has created a relief of $340 \mathrm{~m}$. The cause of this intense erosion of the seafloor is suggested to be the frequent development of hyperpycnal flows. A seismic section across a meander in the distal part of the canyon shows levees formed by overspilled sediments at the outer bend, and a terrace characterized by relatively flat stratified facies at the inner bend. The geological setting and climatic conditions in SW Taiwan (e.g. earthquakes, typhoons, floods), as well as major river-canyon connections (for example, direct input of highly concentrated suspended sediment) would all promote hyperpycnal flow generation. This causes axial incision, canyon wall slumping, and the formation of levees by spill-over deposition in the upper reach of the Kaoping Canyon.
\end{abstract}

C.-S. Chiang $(\bowtie)$

Hsiuping Institute of Technology,

11 Gungye Rd., Dali City,

Taichung, Taiwan, Republic of China

e-mail: wind@mail.hit.edu.tw

H.-S. Yu

Institute of Oceanography, National Taiwan University,

1 Sect. 4 Roosevelt Rd.,

Taipei, Taiwan, Republic of China

\section{Introduction}

That turbidity currents play a major role in the formation of meandering submarine channels has been proposed decades ago. For example, Shepard (1966), after discovering meandering submarine channels in the Monterey fan valleys off California, suggested that the meanders were created by incision in the course of turbidity current activity, whereas spill-over of fine-grained sediments led to the formation of levees along the meander belts. Turbidity current action, as an important mechanism in channel formation and canyon meandering, has been emphasized also in more recent studies (e.g. Pirmez and Imran 2003; Mulder et al. 2003, 2004).

Although terrestrial hyperpycnal flows have been known to occur since the 1880s (Forel 1885), the existence of marine hyperpycnal flows, and their role in forming meandering channels and canyons have been reported only more recently. Thus, Mulder et al. (1997) suggested that the formation of the Var submarine canyon was closely related to hyperpycnal activity.

In marine environments, hyperpycnal flows commonly form during floods at the mouths of small to medium-size rivers when the discharge of suspended sediment reaches concentrations above a density threshold of $36 \mathrm{~kg} / \mathrm{m}^{3}$ (Mulder et al. 2003). Tectonically active margins, such as the Eel River margin in northern California (Sommerfield and Nittrouer 1999), are characterized by small drainage basins with high relief associated with small mountain rivers carrying extremely high sediment loads. Therefore, such rivers are considered good candidates for the generation of hyperpycnal flows (Mulder and Syvitski 1995). They often discharge directly into submarine canyon heads, and thereby increase the intensity of erosion in the canyons due to frequent hyperpycnal flow events. As a 
consequence, meanders may be formed in submarine channels and canyons in the course of time (Mulder et al. 2003). These findings led Mulder et al. (2003) to conclude that marine hyperpycnal flows were excellent candidates to explain the origin of meanders in deep submarine channels and canyons.

Within this context, the purpose of this paper is to test the hypothesis that hyperpycnal flows play an important role in submarine canyon incision and channel meandering, by using the Kaoping submarine canyon offshore SW Taiwan as type locality.

\section{Physical setting}

Along the continental margin of south-west Taiwan, numerous submarine canyons are incised into mostly Pleistocene-Recent sediment successions. The Kaoping Canyon, the largest in this region, begins at the mouth of the Kaoping River, crosses the shelf and slope over a distance of about $260 \mathrm{~km}$, and eventually merges with the northern Manila Trench (Fig. 1). The canyon winds its way down-slope, its course showing two sharp bends en route for the trench axis which subdivide it into three distinct reaches (Chiang and Yu 2006).

The Kaoping submarine canyon is an ideal site for investigating links between potential hyperpycnal flows and canyon formation because of the favourable geological and climatic settings. Thus, it is located along a tectonically active continental margin, the Kaoping River being characterized by a small drainage basin $\left(<3,500 \mathrm{~km}^{2}\right)$ with a high relief $(>3,000 \mathrm{~m})$, adjacent to a very narrow shelf $(<10 \mathrm{~km}$; Yu and Chiang 1997). The Kaoping is a typical, small mountain river (Milliman and Syvitski 1992), draining the south-western coastal plain and flowing for about $100 \mathrm{~km}$ before emptying onto the inner Kaoping Shelf (Fig. 1). It is moderately turbid, with a high suspension load which could generate hyperpycnal flows at its mouth at a rate of about one per 100 years (Mulder and Syvitski 1995).

The head of the canyon is directly connected to the mouth of the river, which would have amplified the erosional capacity of hyperpycnal flows during the shaping of the canyon. In addition, the occurrence of meanders in the down-canyon segment immediately beyond the canyon head facilitates investigating meander evolution in response

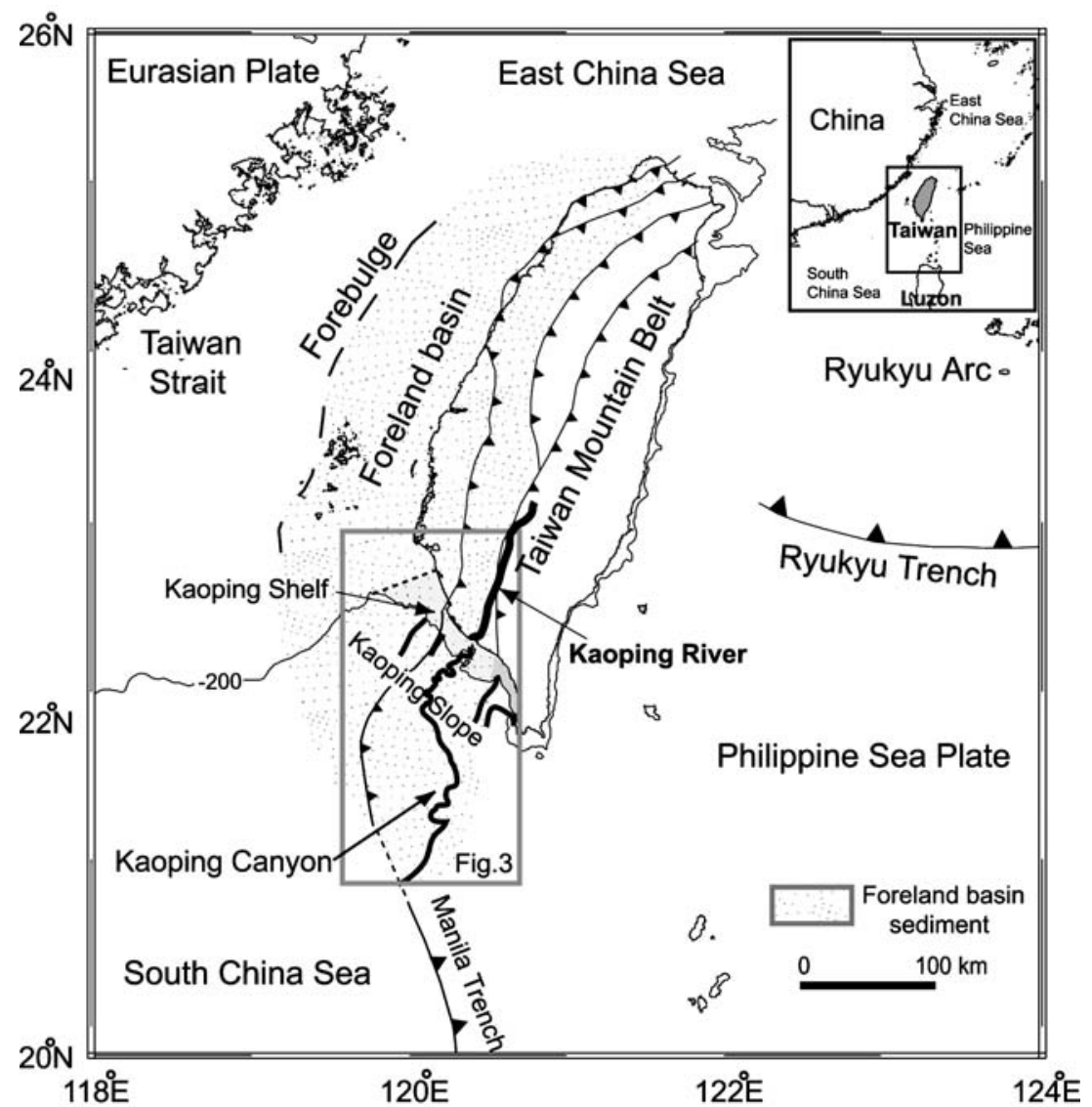

Fig. 1 Tectonic map of Taiwan, showing the Taiwan Mountain Belt and the adjacent western Taiwan foreland basin. The small Kaoping River drains mountainous south-western Taiwan, and discharges its sediment load into the South China Sea. The Kaoping Canyon begins

at the mouth of the Kaoping River, crosses the shelf and slope region, and eventually merges with the northern Manila Trench. Other submarine canyons in the shelf-slope region off SW Taiwan are marked by thick lines 
to possible hyperpycnal flow activity. Finally, the subtropical climate of Taiwan, with a mean annual precipitation of $2.5 \mathrm{~m} /$ year, an average of four typhoons per year, and the occurrence of frequent earthquakes result in high erosion rates (3-6 mm/year) and an average annual sediment yield of about $115 \mathrm{Mt} /$ year in south-western Taiwan (Fig. 2; Dadson et al. 2003). The tectonic setting and subtropical climate are associated with strong mechanical weathering related to earthquakes and storms (Dadson et al. 2004), and moderate chemical weathering (Selvaraj and Chen 2005). Therefore, large earthquake-triggered suspended sediment loads in rivers such as the Kaoping River would tend to be episodically discharged into the ocean in the form of highly concentrated hyperpycnal flows.
Regional geology

The fold-and-thrust belt of Taiwan was formed by oblique collision between the Luzon Arc and the Chinese margin, beginning in the late Miocene-early Pliocene (Suppe 1981; Ho 1988). The foreland region of the Chinese margin was down-flexed in response to the topographic loading of the Taiwan orogen, forming an east-dipping, wedge-shaped foreland basin flanking the Taiwan Mountain Belt (Covey 1984; Yu and Chou 2001), as shown in Fig. 1. Here, the arc-continent collision is actively propagating southwards (Suppe 1987), south-western Taiwan representing the initial collision zone (Lallemand and Tsien 1997) which receives sediment derived from the Taiwan orogen to form

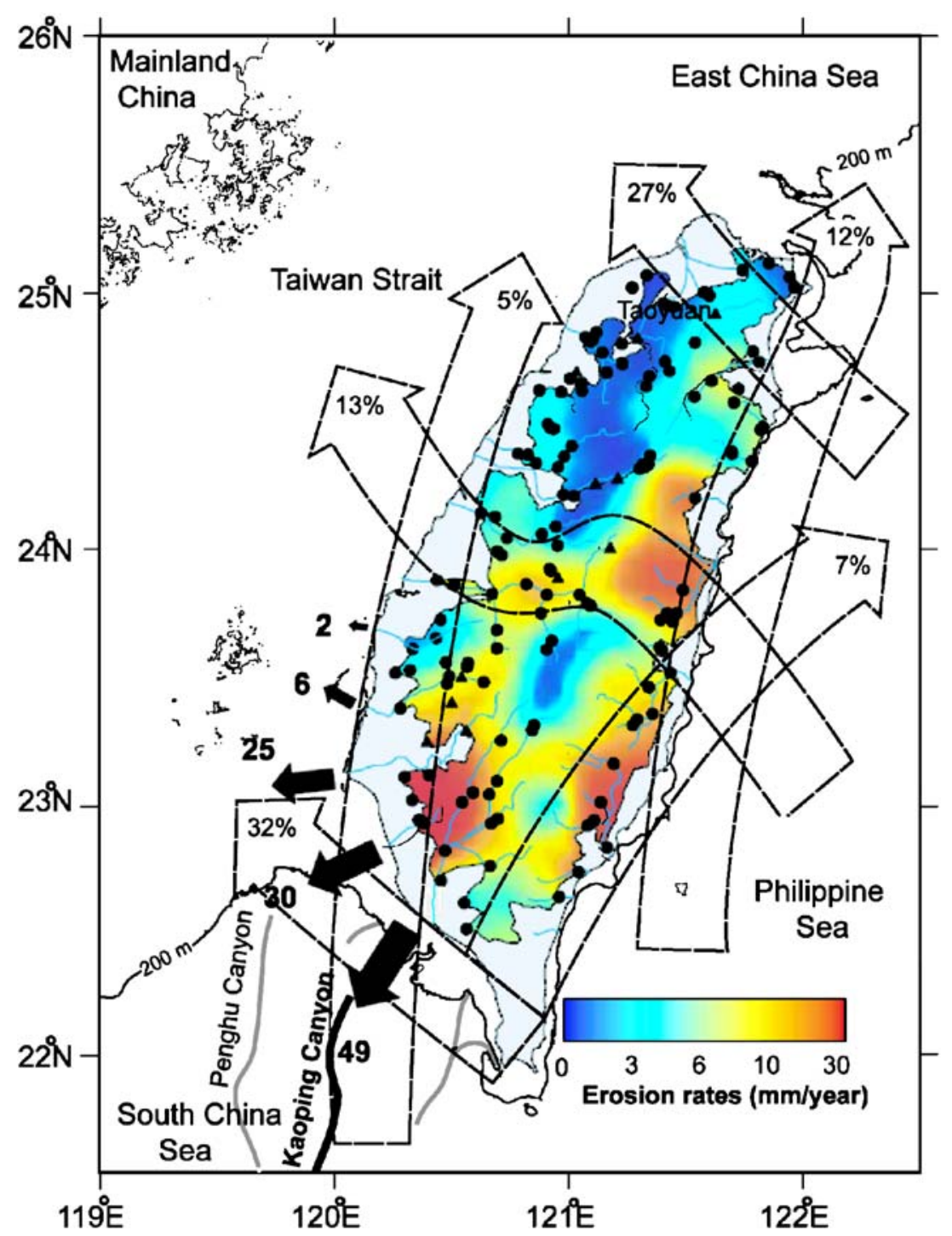

Fig. 2 Map showing characteristic erosion rates, sediment dispersal routes, and typhoon pathways in Taiwan (modified from Dadson et al. 2003). Erosion rates are high in SW Taiwan ( $\sim 60 \mathrm{~mm} /$ year). Closed arrows indicate mean annual coastal suspended sediment fluxes

(million tons/year) for river catchments exceeding $400 \mathrm{~km}^{2}$; again, values are high for SW Taiwan. Open arrows indicate typhoon pathways during the last 100 years. Note that $32 \%$ of typhoons passed through SW Taiwan 
Fig. 3 Map of the study area, including the Kaoping shelf and slope bordered by the Pingtung coastal plain in SW Taiwan. Also shown are the tracks of the 13 seismic and accompanying bathymetric profiles, and of the two Chirp sonar profiles oriented NW-SE normal to the axis of the upper reach of the Kaoping Canyon. Bathymetric cross sections to the lower right illustrate the dimensions of the canyon

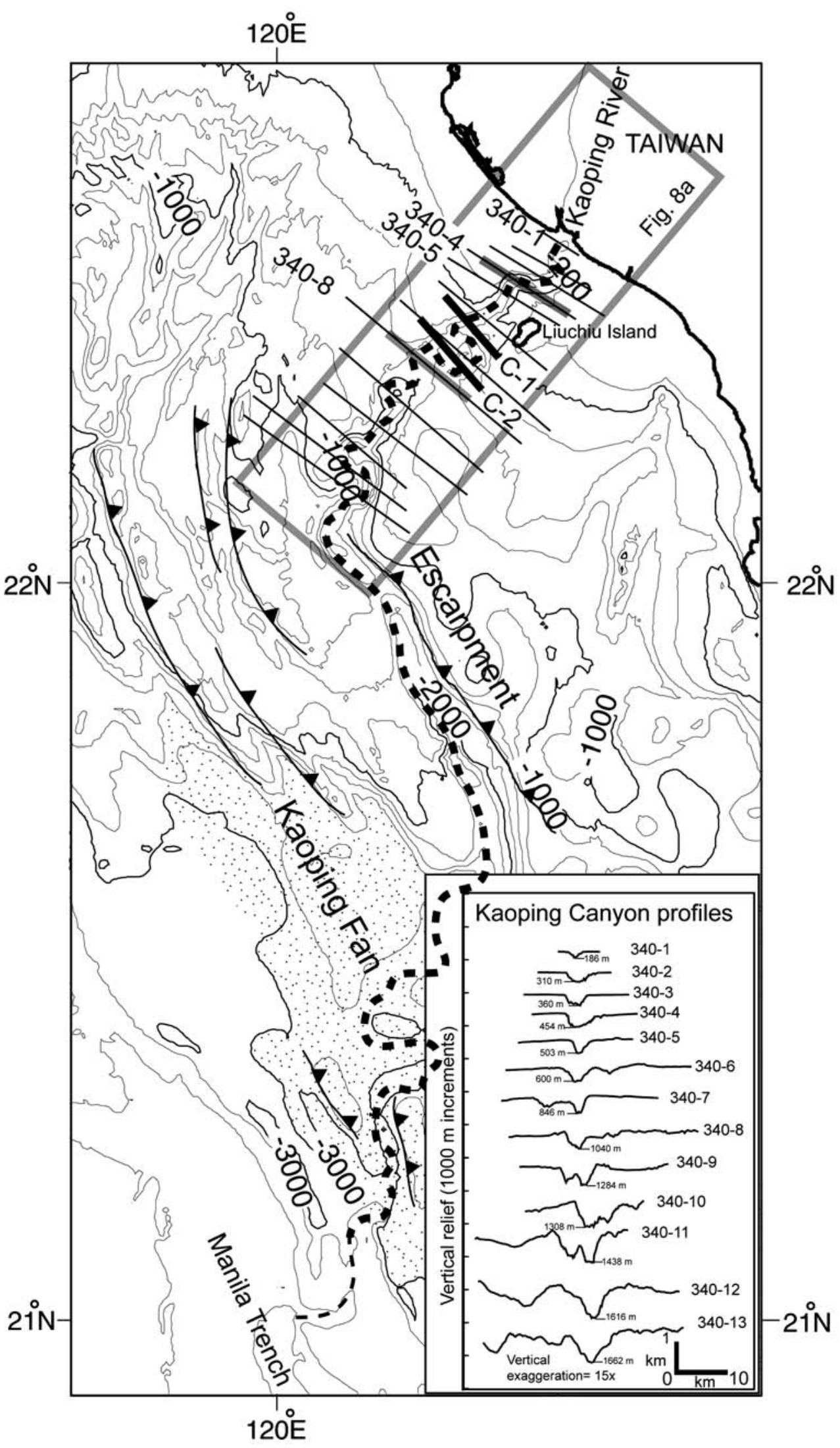


a wedge-top depozone as part of the foreland basin system (Chiang et al. 2004).

In south-western Taiwan, the Pingtung Plain lies west of the Taiwan orogen and is filled by more than 5,000-m-thick Pliocene-Pleistocene sediments derived from the Taiwan orogen (Hsieh 1970). Seawards of the Pingtung Plain lies the Kaoping Shelf. Beyond the Kaoping shelf edge, the Kaoping Slope is a broad, steeply sloping region which extends south-westwards to a water depth of about 3,500 m, where it merges with the northern extension of the Manila Trench of the South China Sea Basin (Fig. 1). Sediments derived from Taiwan have been deposited progressively seawards beyond the Pingtung Plain to form the Kaoping shelf and slope, today representing an underfilled basin in its early evolutionary stage (Yu 2004).

Submarine canyons are major physiographic features on the seafloor off south-west Taiwan, where five distinct canyons incise along the shelf and slope (Fig. 1). The Kaoping Canyon is the largest of these, and hence not only the main pathway for sediments derived from the Taiwan orogen to be delivered to the northern South China Sea, but also the most important route for sediments removed from the foreland basin off SW Taiwan and which infill the northern extension of the Manila Trench.

\section{Materials and methods}

A series of 13 seismic sections were run mostly in a NWSE direction normal to the axis of the upper reach of the Kaoping Canyon, from onboard the R/V Ocean Researcher $I$ of the National Taiwan University (Fig. 3). Accompa- nying bathymetric profiles were recorded by means of a Simrad EK 500 single-beam echo sounder. These profiles cover most of the upper reach of the canyon, over a distance of about $90 \mathrm{~km}$ and including several meanders. An air-gun array was used as seismic sound source; recording was on a 300-m-long, four-channel streamer in Society of Exploration Geophysicists-Y format, coupled with a Digital Field System-V digital seismic recorder. The seismic reflection data were processed using SIOSEIS and PROMAX software, following standard processing procedures.

In addition, two high-resolution Chirp sonar profiles were acquired in a selected section of the canyon, using a BATHY-2000P Chirp sub-bottom profiler (Ocean Data Equipment Corporation, Warwick). Chirp bandwidth ranged from 3 to $11 \mathrm{kHz}$, with a sub-bottom resolution of $8 \mathrm{~cm}$ and a penetration of $100-200 \mathrm{~m}$.

\section{Results}

The Kaoping Canyon head off the Kaoping River mouth is represented by a relatively narrow, V-shaped valley, as shown for profile 340-1 in Fig. 3. South of the head, the canyon increases markedly in size, and becomes U-shaped (profiles 340-2 through 340-5). Canyon width increases from $2.8 \mathrm{~km}$ to about $6 \mathrm{~km}$, and relief from $166 \mathrm{~m}$ at the head to about $400 \mathrm{~m}$ near the shelf edge. On the upper slope, the canyon meanders, and both the width and relief increase substantially, resulting in variable cross-sectional morphologies without distinct V- or U-shaped forms (profiles 6 through 13).

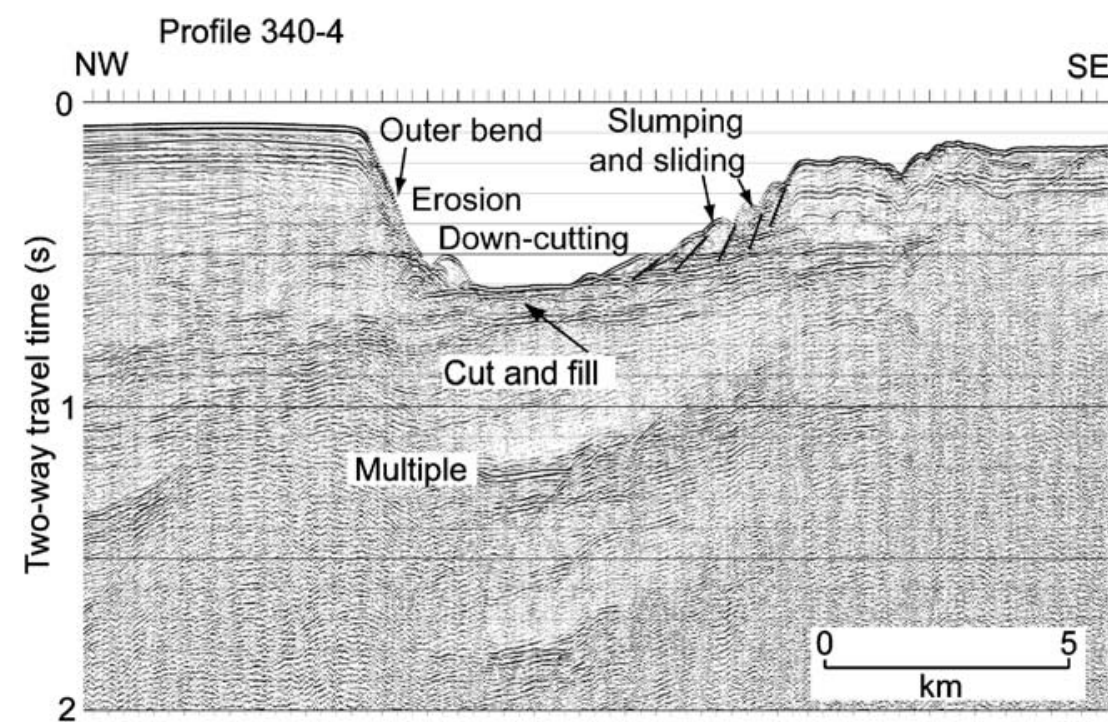

Fig. 4 Seismic profile 340-4 (modified from Chiang and Yu 2006), showing truncation of parallel reflectors against the steep western wall, and down-cutting along an outer bend of the canyon (see Fig. 3 for location). Stepped and curved surfaces along the eastern wall suggest that sliding or slumping of strata in the upper reach may have resulted in gradual slope development along the inner bend of the canyon 
Fig. 5 Seismic profile 340-8, showing down-cutting along the canyon thalweg, and deposition of overspilled sediments along an outer bend, resulting in a terrace characterized by a relatively flat stratified facies along the eastern wall (see Fig. 3 for location)

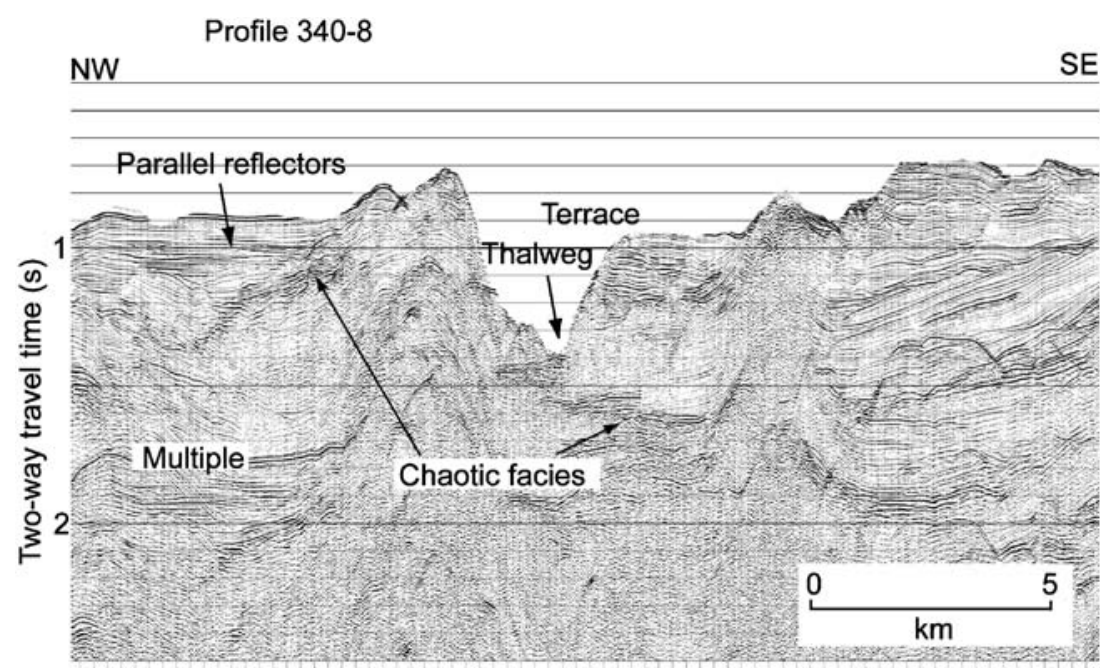

Seismic profile 340-4 (Fig. 4) shows parallel reflectors terminating against the western canyon wall with a smooth sloping surface, indicating erosive truncation due to downcutting of the canyon. The eastern canyon wall, by contrast, is characterized by stepped and curved surfaces, which can be explained by sliding and/or slumping of the strata forming the canyon wall. The seismic characteristics and cross-sectional configuration together suggest that continued downward excavation of the canyon floor, and slumping and/or sliding along the canyon wall have caused the canyon to become deeper and wider on the upper slope, contrasting with the canyon head.

Compared to profile $340-4$, seismic profile 340 8 (Fig. 5), located immediately south-west of a meander on the upper slope at a water depth of about $600 \mathrm{~m}$, shows contrasting morphology and seismic facies. Here, the canyon has a V-shaped cross section with a deep, narrow thalweg, indicating active axial incision. The north-western canyon wall is characterized by an elevated topographic high consisting of chaotic seismic facies. To the west of the topographic high, parallel horizontal reflectors unconformably overlie the flank of the canyon. The chaotic facies of the topographic high suggests this to be a levee without stratified deposits, probably due to rapid deposition or mud diapiric intrusion. The parallel horizontal reflectors along the north-western flank of the canyon at this location are thus interpreted as representing levee deposits of finegrained sediment formed by overspill of presumed hyperpycnal turbidity currents. The south-eastern canyon wall, by contrast, is rimmed by a flat-topped terrace situated about $350 \mathrm{~m}$ above the thalweg. Note that this flat structure resembles a terrace only in a morphological sense.

The seismic facies of this structure is characterized by stratified layers in its upper section and chaotic facies at its base, probably resulting from the deposition of fine particles concentrated at the top of turbidity currents spilling over the canyon wall. Genetically, this terrace is considered to be equivalent to a levee formed by fine sediments spilling over the canyon wall, where they settle out.

Chirp sonar profile C-1 from the distal part of the sinuous segment shows non-deposition of overspilled levees on the seabed of the canyon edges (Fig. 6). By contrast, Chirp sonar profile C-2 from the distal part of the meandering segment shows stratified sediment accumulation of levees along the south-eastern outer bend of the canyon (Fig. 7).
Fig. 6 Chirp sonar profile C-1, showing few diffuse sub-bottom echoes, and a flat or gently sloping relief along the canyon edges, suggesting shallowmarine shelf sedimentation (see Fig. 3 for location)

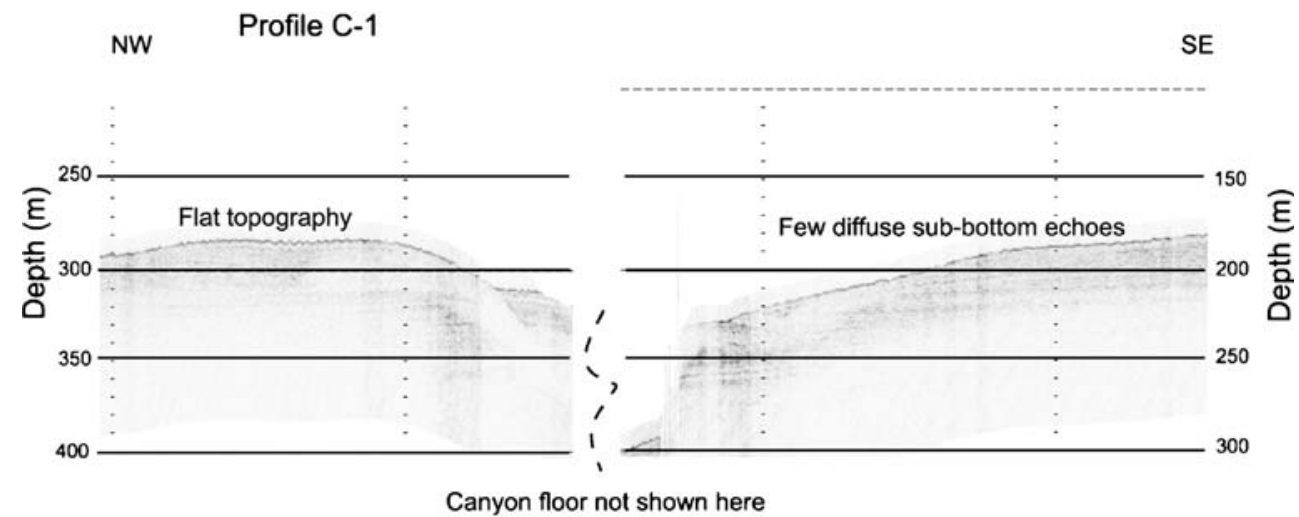


Fig. 7 Chirp sonar profile C-2, showing parallel reflectors possibly resulting from overspilling of a hyperpycnal flow along the canyon edges (see Fig. 3 for location). The top of the levee along the eastern side (outer bends) is higher than that along the western side (inner bends), a difference of about $30 \mathrm{~m}$. Note that the parallel reflectors over the canyon edges occur along meanders (not shown in profile C-1)

Profile C-2

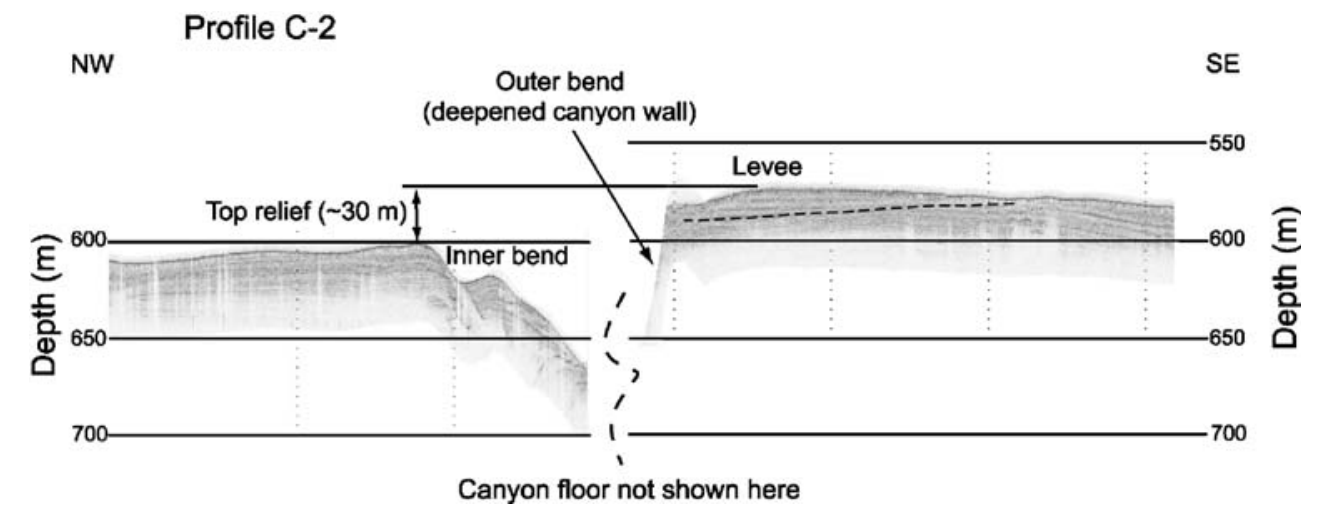

\section{Discussion and conclusions}

In the following, we discuss canyon morphology, seismic expressions of erosive and depositional features, and relations to presumed hyperpycnal flows within the upper reach of the Kaoping Canyon. We have presented evidence of deeply cut canyon thalwegs and slumping features in the deposits of the shallow and flat continental shelf, and levees of stratified facies spilled over the canyon bank possibly by hyperpycnal flows at a meander on the upper slope. These observations suggest that canyon meandering would occur with hyperpycnal flows in the course of time.

Along active margins, the location and orientation of canyons is controlled by tectonics but, in general, all canyons form by down-slope erosion, along both active as well as passive margins. Erosional processes excavate and enlarge a canyon (Shepard 1981). Indeed, the variable cross-sectional morphologies along the course of the Kaoping Canyon indicate differential effects of erosional and depositional events.

In analogy with the Kaoping River, the small Eel River in mountainous northern California is also characterized by very high suspended sediment concentrations estimated to be associated with hyperpycnal flows at a rate of one per 100-year flood events (Mulder et al. 2003). It discharges onto a narrow shelf (10-20 km wide), and hyperpycnal flows travel into the adjacent Eel Canyon. Having geological and climatic characteristics similar to those of the Eel River, the Kaoping River is likely to also produce hyperpycnal flows at its mouth during major flood events. Such concentrated flows would easily reach the head of the Kaoping Canyon because of the direct river-canyon connection (Fig. 1). Notably, Liu et al. (2006) reported an episodic flushing of suspended particles into the canyon head area during a typhoon, which most probably generated a turbidity current in the head area.

Hyperpycnal flows would have instantly eroded the seabed in the proximal part of the Kaoping Canyon. Continued and long-duration hyperpycnal flows would eventually have cut a deep canyon into the Kaoping Shelf, as illustrated by profile 340-4. Down-cutting of the flat shelf strata, and the formation of a very deep canyon segment with a relief exceeding $340 \mathrm{~m}$ indicate intensive erosion in the Kaoping Canyon head region, one order of
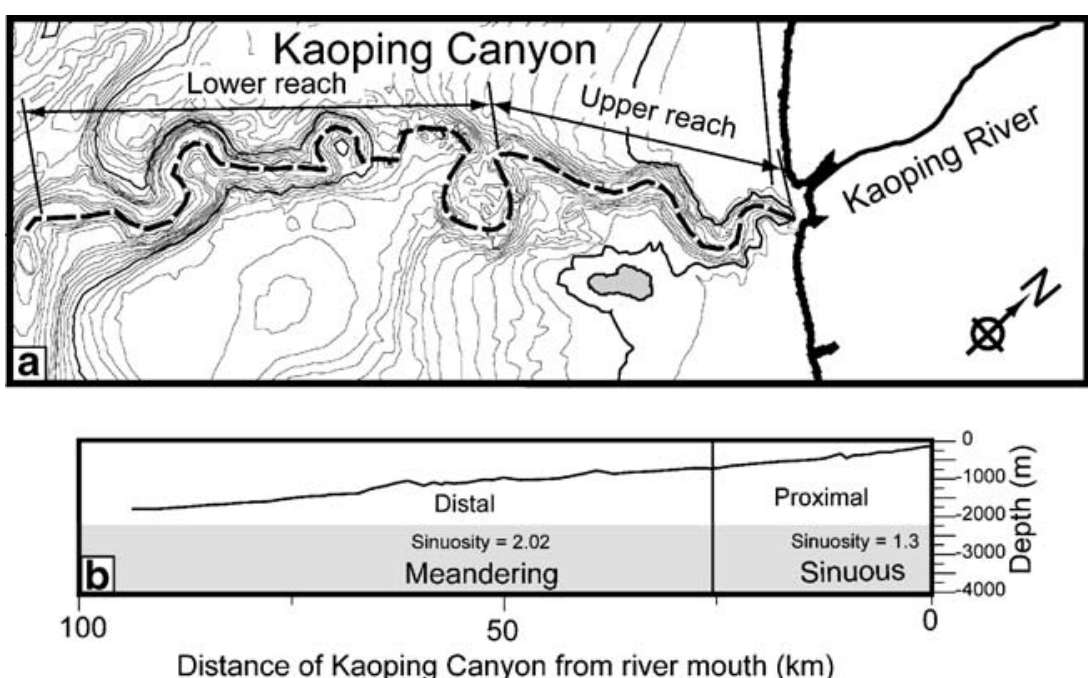

Distance of Kaoping Canyon from river mouth $(\mathrm{km})$

Fig. 8 Inferred hyperpycnal flows in the sinuous and meandering Kaoping Canyon segments. a The canyon course is largely sinuous ( inuosity=1.3) for the first $25.2 \mathrm{~km}$ from the canyon head, subsequently gradually becoming meandering (sinuosity $=2.02$; see Fig. 3 for location). b Sinuosity of the head region of the Kaoping Canyon 
magnitude greater than values of only tens of meters of incision commonly reported for valleys crossing continental shelves (Talling 1998). This would imply powerful erosion by hyperpycnal flows within the canyon.

The lack of tectonic uplift or structural tilting of the Kaoping Shelf suggests that the relatively steep canyon slope of about $1.7^{\circ}$ in the head region is mainly the result of axial incision of down-slope sediment flows. As a general rule, incision at the base of turbidity currents is enhanced when velocity increases on steeper canyon slopes. Steeper slopes of canyon segments induced by uplift accelerate sediment flows and promote incision. This is not the case for the Kaoping Canyon. In other words, incision of this canyon is considered to be due mainly to the action of hyperpycnal flows. Although direct evidence of hyperpycnal plumes at the river mouth is not yet available, hyperpycnal flows at the Kaoping river mouth-canyon connection are here proposed as being the main mechanism controlling the canyon gradient and down-cutting into shelf sediments, eventually forming the Kaoping Canyon.

The terrace flanking the south-eastern wall of a meander bend (Fig. 5) is similar to the terrace and overspilled levees observed in a seismic profile across the Capbreton Canyon off the coast of France and Spain (Mulder et al. 2004). Super-elevation of turbidity currents overtopping the canyon wall at meanders is common in submarine channels (Hay 1987; Peakall et al. 2000). It is suggested that presumed hyperpycnal flows in the upper reach of the Kaoping Canyon could be super-elevated in the outer part of the meander, resulting in overflowing of the canyon wall and the deposition of fine-grained sediments to form levees. Terraces have been observed also in other meandering canyons or channels: e.g. the Golo Canyon (Pichevin et al. 2003), submarine channels of the southern Barbados prism (Huyghe et al. 2004), the Capbreton Canyon (Mulder et al. 2004) and the Cap Timiris Canyon (Antobreh and Krastel 2006).

Our seismic profiles indicate that the sinuous canyon segment proximal to the canyon head is dominated by erosion associated with inferred hyperpycnal flows or turbidity currents (Fig. 8a), but that both erosion and deposition are prevalent along the meandering canyon segment farther down-canyon (Fig. 8b). This is consistent with the Chirp sonar data suggesting that hyperpycnal flows have eroded the proximal part, and sediments are deposited in the meandering part. Liu et al. (2006) proposed that the recent typhoon event of Nakri in 2002 generated strong transport in terms of down-canyon flushing of suspended particles. No sediment was deposited in the Kaoping Canyon head area and up to about $20 \mathrm{~km}$ further offshore. Our study results are in agreement with those of Liu et al. (2006), i.e. down-slope sediment flows eroded the floor and flanks of the sinuous canyon segment. After entering the meandering canyon segment, deposition occurred either by overspilling onto levees outside the canyon or on terraces within the canyon. Indeed, our observations of erosion and deposition along the path of down-slope sediment flows in the Kaoping Canyon are similar to those modelled by Mulder et al. (1998) for the Saguenay Fjord hyperpycnal event of 1663 A.D. in Quebec (Canada). This similarity of sedimentary processes between the Kaoping Canyon and the Saguenay Fjord decreases with distance from the river mouth. This implies the restriction of hyperpycnal flowinduced erosion mainly to the head region of the canyon. Erosion of sediments on the relatively shallow and flat shelf to form a deeply cut canyon with a $340 \mathrm{~m}$ relief close to the river mouth would imply multiple hyperpycnal flow events occurring in the Kaoping Canyon for a long time period. Deposition of overspill sediments to form the levees at the meander bend suggests that presumed hyperpycnal flows in the meandering segments of the canyon could be superelevated in the outer part of the meander, resulting in overflowing of the canyon wall and depositing fine-grained sediments to form levees.

Observations from seismic sections and Chirp sonar profiles across the sinuous and meandering segments of the Kaoping Canyon suggest that hyperpycnal flows or turbidity currents are most likely to occur during flood events, accounting for the erosive and depositional features varying with distance in the canyon head region. Crosssection geometries and erosional and depositional features vary along the canyon course. An analogy can be drawn between hyperpycnal flows operating in the head region of the Kaoping Canyon and the 1663 hyperpycnal event in the Saguenay Fjord, Canada.

Acknowledgements We wish to thank the captain and crew of the $\mathrm{R} / \mathrm{V}$ Ocean Researcher I for help in data collection at sea. Financial support came from the National Science Council, Taiwan. The critical review of the original manuscript by J.C. Chen, Institute of Oceanography, National Taiwan University, is greatly appreciated, as well as comments by the associate editor M.T. Delafontaine.

\section{References}

Antobreh AA, Krastel S (2006) Morphology, seismic characteristics and development of Cap Timiris Canyon, offshore Mauritania: a newly discovered canyon preserved off a major arid climatic region. Mar Petrol Geol 23:37-59

Chiang CS, Yu HS (2006) Morphotectonics and incision of the Kaoping Submarine Canyon, SW Taiwan orogenic wedge. Geomorphology 80:199-213

Chiang CS, Yu HS, Chou YW (2004) Characteristics of the wedge-top depozone of the southern Taiwan foreland basin system. Basin Res 16:65-78

Covey M (1984) Lithofacies analysis and basin reconstruction, PlioPleistocene western Taiwan foredeep. Petrol Geol Taiwan 20:53-83 
Dadson SJ, Hovius N, Chen H, Dade WB, Hsieh ML, Willett SD, Hu JC, Horng MJ, Chen MC, Stark CP, Lague D, Lin JC (2003) Links between erosion, runoff variability and seismicity in the Taiwan orogen. Nature 426:648-651

Dadson SJ, Hovius N, Chen H, Dada WB, Lin JC, Hsu ML, Lin CW, Horng MJ, Chen TC, Milliman J, Stark CP (2004) Earthquaketriggered increase in sediment delivery from an active mountain belt. Geology 32:733-736

Forel FA (1885) Les ravins sous-lacustres des fleuves glaciaires. C R Acad Sci Paris 101(16):725-728

Hay AE (1987) Turbidity currents and submarine channel formation in Rupert Inlet, British Columbia. 1. Surge observations. J Geophys Res 92:2875-2881

Ho CS (1988) An introduction to the geology of Taiwan: explanatory text of the geological map of Taiwan, 2ndnd edn. Central Geological Survey, Ministry of Economic Affairs, Taipei

Hsieh SH (1970) Geology and gravity anomalies of the Pingtung Plain, Taiwan. Proc Geol Soc China 13:76-89

Huyghe P, Foata M, Deville E, Mascle G (2004) Channel profiles through the active thrust front of the southern Barbados prism. Geology 32:429-432

Lallemand SE, Tsien HH (1997) An introduction to active collision in Taiwan. Tectonophysics 274:1-4

Liu JY, Lin HL, Hung JJ (2006) A submarine canyon conduit under typhoon conditions off southern Taiwan. Deep-Sea Res 53:223240

Milliman JD, Syvitski JPM (1992) Geomorphic/tectonic control of sediment discharge to the oceans: the importance of small mountainous rivers. J Geol 100:525-544

Mulder T, Syvitski JPM (1995) Turbidity currents generated at river mouths during exceptional discharges to the world oceans. J Geol 103:285-299

Mulder T, Savoye B, Syvitski JPM, Parize O (1997) Hyperpycnal turbidity currents at the head of the Var Canyon? Hydrological data and geological observations. Oceanol Acta 20:607-626

Mulder T, Syvitski JPM, Skene KI (1998) Modelling of erosion and deposition by turbidity currents generated at river mouths. J Sediment Res 68:124-137

Mulder T, Syvitski JPM, Migeon S, Faugères JC, Savoye B (2003) Marine hyperpycnal flows: initiation, behavior and related deposits. A review. Mar Petrol Geol 20:861-882
Mulder T, Cirac P, Gaudin M, Bourillet JF, Tranier J, Normand A, Weber O, Griboulard R, Jouanneau JM, Anschutz P, Jorissen FJ (2004) Understanding continent-ocean sediment transfer. EOS $85: 257-262$

Peakall J, McCarffrey B, Kneller B (2000) A process model for the evolution, morphology, and architecture of sinuous submarine channels. J Sediment Res 70:434-448

Pichevin L, Mulder T, Savoye B, Gervais A, Cremer M, Piper DJW (2003) The Golo submarine turbidite system (east Corsica margin): morphology and processes of terrace formation from high-resolution seismic reflection profiles. Geo-Mar Lett 23:117124

Pirmez C, Imran J (2003) Reconstruction of turbidity currents in Amazon Channel. Mar Petrol Geol 20:823-849

Selvaraj K, Chen CTA (2005) Moderate chemical weathering of subtropical Taiwan: constraint from solid-phase geochemistry of sediments and sedimentary rocks. J Geol 114:101-116

Shepard FP (1966) Meander in valley crossing a deep-sea fan. Science 154:385-386

Shepard FP (1981) Submarine canyons; multiple causes and long-time persistence. Am Assoc Pet Geol Bull 65:1062-1077

Sommerfield CK, Nittrouer CA (1999) Modern accumulation rates and a sediment budget for the Eel shelf: a flood-dominated depositional environment. Mar Geol 154:227-241

Suppe J (1981) Mechanics of mountain building and metamorphism in Taiwan. Geol Soc China Mem 4:67-89

Suppe J (1987) The active Taiwan mountain belt. In: Schaer J, Rogers $\mathrm{J}$ (eds) Comparative anatomy of mountain ranges. Princeton University Press, Princeton, pp 277-293

Talling PJ (1998) How and where do incised valleys form if sea level remains above the shelf edges? Geology 26:87-90

Yu HS (2004) An under-filled foreland basin in the northern South China Sea off Southwest Taiwan: incipient collision and foreland sedimentation. In: Clift P, Wang P, Kuhnt W, Hall R, Tada R (eds) Continent-ocean interactions within East Asian marginal seas. Geophys Monogr Ser 149:159-173

Yu HS, Chiang CS (1997) The Kaoping Shelf: morphology and tectonic significance. J Asian Earth Sci 15:9-18

Yu HS, Chou YW (2001) Characteristics and development of the flexural forebulge and basal unconformity of Western Taiwan Foreland Basin. Tectonophysics 333:277-291 